\title{
The implementation of sustainable concept in waste management through project life cycle process in Gold Coast
}

\author{
Zhabrinna $^{1, *}$ and M. Mirza Abdillah Pratama ${ }^{2}$ \\ ${ }^{1}$ School of Engineering and Physical Science, University of Birmingham, Birmingham, United \\ Kingdom \\ ${ }^{2}$ Department of Civil Engineering, Faculty of Engineering, Universitas Negeri Malang, Malang, \\ Indonesia
}

\begin{abstract}
The issue regarding sustainability has emerged significantly in the construction industry. The appealing concept and the future benefits of sustainability have enamoured people to implement this notion progressively. This situation resulted in a trend in the architectural and engineering world. The Gold Coast city, which is located in the southeast of the Australian state of Queensland, is one of the world leading examples in which a government has put a green legacy as the concern in its development. One of the implementations of its sustainability concept is described in its waste management. This study explores the waste management in Gold Coast city in three stages of the project life cycle (PLC): design, construction, and operation. The cost-benefit analysis in qualitative and quantitative approach will be employed to provide the explanation of cost reduction that is achieved by the implementation of specific actions. However, the result of this study shows that the implementation of waste management does not only benefit in cost, but also many other aspects such as energy, built-environment, diversity, carbon critical design, and community lifestyle. This exploration can be the reference to the best practice of sustainability concept implementation in waste management.
\end{abstract}

\section{Introduction}

Sustainability emerges as a significant issue in the worldwide construction industry. Many foremost developers and contractor and consultant companies make remarkable movements in sustainability and innovation $[1,2]$. Some noteworthy results are BedZED and Masdar City. The appealing concept and future benefits of sustainability have enamoured people to implement this concept progressively. This movement has made sustainability emerge as a trend in the architectural and engineering (AEC) world [3]. This paper will discuss the sustainability concept that is implemented in the waste management during the life cycle of a project from its construction phase to operation and maintenance phase.

* Corresponding author: zhabrinnas@gmail.com 
This paper's purpose is to explore the particular actions in the waste management that will be performed to reduce carbon emission. This paper explores the key factors of uncertainty, the identification of some specific actions that can be implemented, and generates simple cost-benefit analysis (CBA). This paper also relates the performance benchmarking based on the Australian certification system, Green Star. Furthermore, the relation with the other sustainability key elements will also be explored in this paper.

The general approach of waste management is by reducing and recycling waste. However, in this case, the approach is expanded to also optimise the utilisation of waste to acquire benefits for society. The waste management will also be integrated with the existing system in Gold Coast city. The significant source of uncertainty during the construction process is the technique and methods which are used in construction. While in the longer term, the more prominent factors in waste management come from the number of occupants and their behaviour. The different origin and background of the residents will affect their lifestyle, behaviour and the amount of waste produced.

\section{Specific actions and cost benefit analysis}

Waste is a distinctive sector which carries the potential to be a greenhouse gas (GHG) emissions' major saver. The prevention and the restoration of waste, such as waste disposal and treatment, can avoid emissions in all other economic sectors [4]. The lifestyle, such as the selection of things we use and the way we dispose of them may also compose a significant difference in the total amount of waste and greenhouse gas produced [5].

\subsection{Specific actions}

Every action of waste management undertaken yield greenhouse gas, both directly (e.g. emissions generated from the process of recycling) and indirectly (i.e. over energy consumption) [4]. The specific actions in this paper will be divided into three: during design, construction phase, and operation.

\subsubsection{During design}

Sustainability principle must be considered and implemented from the beginning. During the design stage, there are five strategies that can be implemented. To avoid waste production in the construction field $[6,7]$, the first action is to optimise the usage of prefabricated components. Prefabricated components have benefits in the efficiency of human resources, effective working, and the optimisation of time. Th second strategy is to set the materials standardisation. The materials standardisation can minimise the potency of error and fault in material type and size during construction. Thirdly, specific action conducted during the design process is the consideration of a material's efficiency. The design must have considered the type of materials and its size from the beginning of the project to support the sustainability in the future. In line with the Queensland Forward Procurement Plan [8] to select innovative suppliers that embrace the sustainable platform in Queensland, the fourth action is to procure suppliers that use eco-friendly packaging and manage package collection after delivery. This way is conducted to minimise waste during the construction process, as well as a commitment to support the environment. The last strategy in this stage is to create a plan of the waste flow and the disposal area, hence the waste flow is clearly identified and makes it easier to be done [9]. 


\subsubsection{Construction period}

There are five specific actions during the construction period. First, to promote waste avoidance and reduction habit to the workers. The advantage of waste avoidance far outweighs any other waste treatment, even in which energy is recovered during the practice [4]. Secondly, optimise regular waste collection service to the landfill disposal and recycling centre. This service already exists in Gold Coast, known as Reedy Creek Commercial Landfill, thus the routine waste collection schedule can be followed [10]. Reedy Creek Commercial Landfill also accepts construction waste such as concrete, metals, and so on. Furthermore, this landfill is developed and integrated with the Reedy Creek Recycling Centre and the Reedy Creek Recycle Market [11].

The third is minimising storage needed by 'just in time' materials scheduling. This strategy also evades the possibility of materials and tools' destruction when in storage. Fourth, reuse excavated soil for heaps, or also known as cut \& fill. Ultimately, the last strategy in this phase is to use top soil and foundation excavation for grass lawns. Since the green space is one of the points in establishing a sustainable environment [9], there will be a need of soil for grass lawns. This need will be fulfilled by using the uncontaminated top soil and soil from foundation excavation.

\subsubsection{Operation period}

The action plans are linked to the research of the recent existing situation in Gold Coast. The action plans will be integrated with the current situation, services, and policy in this area. Gold Coast itself is already well-developed in term of waste management. There is a regular collection of trash from house to house and from apartments [6]. There is also an existing drop-off service in which the resident can bring their waste by their car and drop it off at the drop-off points [12]. There is also an online waste service, in which residents can book a waste collection service online, replace lost or stolen bins, report a missed bin collection, and so forth [12].

The second specific action is following domestic waste management plan. In Gold Coast, the system of waste separation is divided into three categories: general waste (red or dark green lid), recycling (yellow lid), and optional green waste (lime green lid) [10]. The third action is the initiative use of waste as fertiliser and electricity (Biomass) $[13,14]$. This action is also a form of support to the other key elements in sustainability which are diversity and eco-friendly energy production. The last action is to promote waste avoidance (reduce), re-use, and recycling behaviour to the community [15]. These actions are in line with the local government resolution called Solid Waste Strategy 2024 [13].

\subsection{Cost benefit analysis}

The cost-benefit analysis will be conducted in two approaches; qualitative and quantitative analysis. This part provides the explanation of cost reduction achieved by the implementation of specific actions.

\subsubsection{Qualitative analysis}

This approach shows the analysis of benefits qualitatively from implementing the specific actions. The costs and benefits are identified qualitatively by applying a rating system. The rating system will be valued with a 1-5 scale, in which one means no significant impact, and five is rated for an action which gives the most significant impact. The specific action 
will be considered as beneficial if the result of the cost-benefit ratio is more than one. The detail is presented in Table 3.1 below.

Table 1. Qualitative analysis.

\begin{tabular}{|c|c|c|c|c|c|}
\hline $\begin{array}{l}\text { Specific } \\
\text { Actions }\end{array}$ & Benefits & $\begin{array}{c}\text { Benefits' } \\
\text { Rating }\end{array}$ & Costs & $\begin{array}{l}\text { Costs' } \\
\text { Rating }\end{array}$ & $\begin{array}{c}\text { Benefit/Cost } \\
\text { Ratio }\end{array}$ \\
\hline \multicolumn{6}{|c|}{ During Design } \\
\hline $\begin{array}{l}\text { Optimisation of } \\
\text { the } \\
\text { prefabricated } \\
\text { components }\end{array}$ & $\begin{array}{l}\text { Waste } \\
\text { avoidance, } \\
\text { efficiency in } \\
\text { work and } \\
\text { resources }\end{array}$ & 3 & $\begin{array}{l}\text { No significant } \\
\text { cost }\end{array}$ & 1 & 3 \\
\hline $\begin{array}{l}\text { Materials } \\
\text { standardisation }\end{array}$ & $\begin{array}{l}\text { Less potency } \\
\text { of error and } \\
\text { waste }\end{array}$ & 2 & $\begin{array}{l}\text { No significant } \\
\text { cost }\end{array}$ & 1 & 2 \\
\hline $\begin{array}{l}\text { Material } \\
\text { efficiency } \\
\text { consideration }\end{array}$ & $\begin{array}{l}\text { Waste } \\
\text { avoidance, } \\
\text { carbon } \\
\text { emission } \\
\text { reduction } \\
\end{array}$ & 4 & $\begin{array}{l}\text { No significant } \\
\text { cost }\end{array}$ & 1 & 4 \\
\hline $\begin{array}{l}\text { Procuring } \\
\text { suppliers with } \\
\text { eco-friendly } \\
\text { packaging and } \\
\text { packages } \\
\text { collection } \\
\text { facility }\end{array}$ & $\begin{array}{l}\text { Carbon } \\
\text { emission } \\
\text { reduction }\end{array}$ & 3 & $\begin{array}{l}\text { A bit more } \\
\text { expensive } \\
\text { than the other } \\
\text { conventional } \\
\text { suppliers }\end{array}$ & 2 & 1,5 \\
\hline $\begin{array}{l}\text { Creating a plan } \\
\text { for the flow of } \\
\text { the waste and } \\
\text { the disposal } \\
\text { area }\end{array}$ & $\begin{array}{l}\text { Better waste } \\
\text { arrangement }\end{array}$ & 3 & $\begin{array}{l}\text { No significant } \\
\text { cost }\end{array}$ & 1 & 3 \\
\hline \multicolumn{6}{|c|}{ Construction Period } \\
\hline $\begin{array}{l}\text { Promote } \\
\text { avoiding and } \\
\text { reducing waste } \\
\text { habit to the } \\
\text { workers }\end{array}$ & $\begin{array}{l}\text { Waste } \\
\text { avoidance, } \\
\text { carbon } \\
\text { emission } \\
\text { reduction } \\
\end{array}$ & 3 & $\begin{array}{l}\text { No significant } \\
\text { cost }\end{array}$ & 1 & 3 \\
\hline $\begin{array}{l}\text { Routine waste } \\
\text { collection } \\
\text { service to the } \\
\text { landfill and } \\
\text { recycling } \\
\text { centre }\end{array}$ & $\begin{array}{l}\text { Better waste } \\
\text { arrangement }\end{array}$ & 5 & $\begin{array}{l}\text { Regular waste } \\
\text { collection cost }\end{array}$ & 3 & 1,7 \\
\hline $\begin{array}{l}\text { Minimising } \\
\text { storage needed } \\
\text { by 'just in } \\
\text { time' materials } \\
\text { scheduling }\end{array}$ & $\begin{array}{l}\text { Waste } \\
\text { avoidance }\end{array}$ & 3 & $\begin{array}{l}\text { No significant } \\
\text { cost }\end{array}$ & 1 & 3 \\
\hline Cut \& Fill & $\begin{array}{l}\text { Carbon } \\
\text { emission } \\
\text { reduction, } \\
\text { efficiency in } \\
\text { work and } \\
\text { resources }\end{array}$ & 2 & $\begin{array}{l}\text { No significant } \\
\text { cost }\end{array}$ & 1 & 2 \\
\hline
\end{tabular}




\begin{tabular}{|c|c|c|c|c|c|}
\hline $\begin{array}{l}\text { Specific } \\
\text { Actions }\end{array}$ & Benefits & $\begin{array}{c}\text { Benefits' } \\
\text { Rating }\end{array}$ & Costs & $\begin{array}{l}\text { Costs' } \\
\text { Rating }\end{array}$ & $\begin{array}{c}\text { Benefit/Cost } \\
\text { Ratio }\end{array}$ \\
\hline $\begin{array}{l}\text { Use top soil } \\
\text { and foundation } \\
\text { excavation for } \\
\text { grass lawn }\end{array}$ & $\begin{array}{l}\text { Carbon } \\
\text { emission } \\
\text { reduction, } \\
\text { efficiency in } \\
\text { work and } \\
\text { resources } \\
\end{array}$ & 2 & $\begin{array}{l}\text { No significant } \\
\text { cost }\end{array}$ & 1 & 2 \\
\hline \multicolumn{6}{|c|}{ Operation Period } \\
\hline $\begin{array}{l}\text { Waste } \\
\text { collection \& } \\
\text { recycling } \\
\text { service }\end{array}$ & $\begin{array}{l}\text { Better waste } \\
\text { arrangement }\end{array}$ & 4 & $\begin{array}{l}\text { Regular waste } \\
\text { collection cost }\end{array}$ & 2 & 2 \\
\hline $\begin{array}{l}\text { Domestic } \\
\text { waste } \\
\text { management } \\
\text { plan } \\
\end{array}$ & $\begin{array}{l}\text { Better waste } \\
\text { arrangement }\end{array}$ & 4 & $\begin{array}{l}\text { Installation } \\
\text { cost, } \\
\text { maintenance } \\
\text { cost } \\
\end{array}$ & 3 & 1,3 \\
\hline $\begin{array}{l}\text { Initiative use of } \\
\text { waste as } \\
\text { fertiliser and } \\
\text { electricity } \\
\text { (Biomass) }\end{array}$ & $\begin{array}{l}\text { Economic } \\
\text { benefit, } \\
\text { support } \\
\text { diversity, } \\
\text { long-term } \\
\text { investment in } \\
\text { energy }\end{array}$ & 5 & $\begin{array}{l}\text { Installation } \\
\text { cost, } \\
\text { maintenance } \\
\text { cost }\end{array}$ & 3 & 1,7 \\
\hline $\begin{array}{l}\text { Promote waste } \\
\text { avoidance, } \\
\text { reuse, and } \\
\text { recycling } \\
\text { behaviour to } \\
\text { the community }\end{array}$ & $\begin{array}{l}\text { Waste } \\
\text { avoidance, } \\
\text { carbon } \\
\text { emission } \\
\text { reduction }\end{array}$ & 5 & $\begin{array}{l}\text { No significant } \\
\text { cost }\end{array}$ & 1 & 5 \\
\hline
\end{tabular}

\subsubsection{Quantitative analysis}

The construction industry contributes a significant amount of waste and carbon emission to the world. Waste management in the construction phase can be one of the problem's solutions in this case. In addition, waste management is not only beneficial for the environment, but it can also contribute to the cost reduction in the construction projects [16]. By using WRAP's Net Waste Tool, the table below shows the result of the analysis of cost and benefit values. This analysis also calculates the investment cost for specific actions taken in the operation stage. 
Table 2. Cost for waste management investment.

\begin{tabular}{|c|c|c|}
\hline $\begin{array}{c}\text { Investment for Waste } \\
\text { Management }\end{array}$ & Costs & Sources \\
\hline $\begin{array}{l}\text { Site Waste Management Plan } \\
\text { (SWMP) }\end{array}$ & $\begin{array}{c}£ 1,640 \\
\text { (for } £ 13.5 \mathrm{~m} \text { construction value) }\end{array}$ & {$[16]$} \\
\hline Logistics management on site & $\begin{array}{c}£ 1,080 \\
\text { (for } £ 13.5 \mathrm{~m} \text { construction value) }\end{array}$ & {$[16]$} \\
\hline Training and socialisation & $\begin{array}{c}£ 1,530 \\
\text { (for } £ 13.5 \mathrm{~m} \text { construction value) }\end{array}$ & {$[16]$} \\
\hline $\begin{array}{l}\text { Regular waste collection } \\
\text { during construction }\end{array}$ & AU $\$ 96.90$ or $£ 58.63$ per tonne & $\begin{array}{l}{[10]} \\
{[17]}\end{array}$ \\
\hline $\begin{array}{l}\text { Regular waste collection } \\
\text { during operation }\end{array}$ & AU $\$ 24.40$ or $£ 14.76$ per year & $\begin{array}{l}{[10]} \\
{[17]}\end{array}$ \\
\hline $\begin{array}{l}\text { Installation and maintenance } \\
\text { cost of fertiliser processing }\end{array}$ & $£ 20$ & Estimated cost \\
\hline $\begin{array}{l}\text { Installation and maintenance } \\
\text { cost of biomass }\end{array}$ & $\begin{array}{c}\text { AU\$430,000 or } £ 260,182.62 \\
\text { per } 1 \mathrm{MW}\end{array}$ & $\begin{array}{l}{[18]} \\
{[17]}\end{array}$ \\
\hline $\begin{array}{l}\text { Total cost for waste } \\
\text { management investment }\end{array}$ & $£ 264,549.89$ & Calculation \\
\hline
\end{tabular}

Table 3. Benefits gained by waste management implementation.

\begin{tabular}{|l|c|c|c|c|}
\hline \multicolumn{1}{|c|}{ Aspect } & Baseline & Target & $\begin{array}{c}\text { Estimated } \\
\text { Value (£) }\end{array}$ & $\begin{array}{c}\text { Improvement } \\
\text { Percentage of } \\
\mathbf{f 1 3 . 5 m} \\
\text { Construction Value }\end{array}$ \\
\hline Value of materials wasted & $£ 499,705$ & $£ 241,515$ & $£ 258,190$ & $1.91 \%$ \\
\hline Cost of waste disposal & $£ 99,661$ & $£ 49,246$ & $£ 50,415$ & $0.37 \%$ \\
\hline Total benefits saved & $£ 599,366$ & $£ 290,761$ & $£ 308,605$ & $2.28 \%$ \\
\hline
\end{tabular}

Table 4. Benefits gained by waste management implementation.

\begin{tabular}{|l|c|}
\hline Total cost for waste management investment & $£ 264,549.89$ \\
\hline Total benefits gained by waste management implementation & $£ 308,606$ \\
\hline Total benefits of $£ 13.5 \mathrm{~m}$ construction value & $£ 44,036.11$ \\
\hline
\end{tabular}

\section{Benchmarking}

The commitment of Gold Coast City has set environment and sustainability standards throughout the planning and delivery lifecycle as a target. The benchmarks commonly used are sustainability standard and client/user satisfaction. For the sustainability, the benchmarking system used is the Green Star, whilst the benchmark of client/user satisfaction is defined through surveys and feedbacks.

Green Star is an Australian certification system that is a very well-established rating system. Most new commercial buildings aim for a 5-star Green Star rating [19]. There are six levels of performance in this system which rank from minimum practice (1 star), average practice ( 2 star), good practice (3 star), best practice (4 star), Australian excellence (5 star), and world leadership (6 star) [20]. 
There are two important credit points that are put on the concern. First is construction and demolition waste credit which is rewarded to a project which practices the minimum amount of construction and demolition waste that is disposed to landfill. The most impressive project so far which has achieved 6 Star Green Star is Frasers Property Australia's new Perth office which has successfully managed to only sent $0.35 \mathrm{~kg}$ per $\mathrm{m} 2$ construction and demolition waste to landfill [21]. The second credit point is waste generated during the operation. To achieve the standard of 5-star rating, there is maximum $40 \%$ of waste disposed to landfill.

\section{Interdependency}

There are mutual relationships between waste management and the other key elements. In addition, the undertaken actions in waste management and its interdependencies are also related to the carbon critical design and sustainability concept. Several specific actions taken to manage waste have both indirect and direct impacts on the energy consumption. The indirect impact can be in the form of the energy needed for transportation and material production. Several actions that have an indirect impact on the energy efficiency are, the plan of waste flow and the disposal area that leads to the less energy consumption for the transportation of waste. The other example is to use efficient materials such as soil in cut and fill, and the reuse of excavation soil for grass lawn.

Furthermore, waste management also results in a direct impact on the energy efficiency, for example, the initiative uses of waste for biomass in the operation stage. Electricity produced by biomass can reduce or even substitute the conventional electricity from coal. This action can be considered as a long-term investment in energy, besides it is also economically and environmentally beneficial. The other action which gives a direct impact to the other key elements is the initiative use of waste as fertiliser. This action will support diversity restoration and revive the local identity of Gold Coast city. In general, all of the specific actions also promote low carbon emission and green lifestyle to not only the community and residents, but also to all parties that are involved in the project including the construction workers.

\section{Conclusion}

The integrated waste management system is conducted to perform the sustainability concept and critical carbon design. The implementation of this system is grouped into three stages, where each stage consists of several specific actions that address waste management in certain periods. The cost benefit analysis performed shows that the waste management actions in Gold Coast are economically beneficial. The undertaking of those specific actions is also related to the other main elements, such as energy, biodiversity, transportation, and sustainable community.

\section{References}

1. H. Aylie, B.S. Gan, S. As'ad, and M.M.A. Pratama, Parametric Study of the Load Carrying Capacity of Functionally Graded Concrete of Flexural Members, Int. J. Eng. Technol. Innov.Int. J. Eng. Technol. Innov., vol. 233-241, no. 5, (2015)

2. B.S. Gan, H. Aylie, and M.M.A. Pratama, The behavior of graded concrete, an experimental study, in: Procedia Engineering, Procedia Engineering, pp. 885-891, (2015) 
3. M. M. A. Pratama et al., Effect of concrete strength gradation to the compressive strength of graded concrete, a numerical approach, (2017)

4. UNEP, Waste and Climate Change: Global Trends and Strategy Framework, (2010)

5. EPA. Climate Change and Waste, (2016)

6. City of Gold Coast, Gold Coast Waste Management Annual Performance Plan 20516, City of Gold Coast, (2016)

7. Queensland Government, Waste Reduction and Recycling Act, Office of the Queensland Parliamentary Counsel, (2011)

8. The Queensland Government, Forward procurement plan for the Gold Coast 2018 Commonwealth Games, The Queensland Government, (2014)

9. The Queensland Government, Parklands Priority Development Area Development Scheme,"The Queensland Government, (2013)

10. Gold Coast City Council. City of Gold Coast, (2017)

11. City of Gold Coast. Reedy Creek Commercial Landfill. [Online]. http://www.goldcoast.qld.gov.au/environment/reedy-creek-commercial-wasterecycling-centre-25364.html

12. City of Gold Coast. Waste and recycling. [Online]. http://www.goldcoast.qld.gov.au/environment/waste-recycling-282.html

13. City of Gold Coast, Solid Waste Strategy 2024, City of Gold Coast, (2015)

14. City of Gold Coast, Solid Waste Strategy Consultation Report 2015 - Maintaining our resources for a sustainable future, City of Gold Coast, Rowland, (2015)

15. EHP, Waste - everybody's responsibility: Queensland Waste Avoidance and Resource Productivity Strategy (2014-2024), Department of Environment and Heritage Protection, Brisbane, (2014)

16. WRAP. Assesing the Costs and Benefits of Reducing Waste in Construction. [Online]. http://www.wrap.org.uk/sites/files/wrap/Southwark\%20IWMF\%20CBA\%20FINAL.d oc.pdf

17. X-Rates. (2017) Currency Calculator. [Online]. http://www.X-rates.com

18. C.R. Stucley et al., Biomass Energy Production in Australia: Status, Costs and Opportunities for Major Technologies, An Australian Government Initiative, Kingston, (2004)

19. Kevin Hastings, Duane Loader, Richard Palmer, and Laura and Crawford, An Overview of the Rating Tool Landscape in Australia, WSP Parsons Brinckerhoff, Adelaide, (2015)

20. Green Building Council of Australia. (2015) Green Star. [Online]. http://new.gbca.org.au/green-star/

21. Green Building Council of Australia. (2015) A 6 Star Green Star - Interior that pushed the waste boundaries. [Online]. http://new.gbca.org.au/showcase/projects/6$\underline{\text { star-green-star-interior-pushed-waste-boundaries/ }}$ 